\title{
Cerebrospinal fluid lactic acidosis in bacterial meningitis
}

\author{
J EROSS, M SILINK, AND D DORMAN
}

Department of Endocrinology and Department of Bacteriology, Royal Alexandra Hospital for Children, Camperdown, New South Wales, Australia

SUMMARY A rapid, microenzymatic method was used to measure cerebrospinal fluid lactate levels in 205 children with suspected bacterial meningitis. Fifty children with normal CSF containing fewer than $0.005 \times 10^{9} / 1 \mathrm{WBC}$, no segmented neutrophils, glucose $3.4 \pm 0.8 \mathrm{mmol} / \mathrm{l}(61 \cdot 2 \pm 14.4$ $\mathrm{mg} / 100 \mathrm{ml})$, and a protein of less than $0.30 \mathrm{~g} / 1$ had CSF lactate levels below $2.0 \mathrm{mmol} / 1(18 \mathrm{mg} /$ $100 \mathrm{ml}$ ) (mean and standard deviation $1.3 \pm 0.3 \mathrm{mmol} / 1(11.8 \pm 2.7 \mathrm{mg} / 100 \mathrm{ml})$ ). In 31 cases of proved viral meningitis as with 58 cases of clinically diagnosed viral meningitis, levels were below $3.8 \mathrm{mmol} / \mathrm{l}(34.5 \mathrm{mg} / 100 \mathrm{ml})$, being $2.3 \pm 0.6 \mathrm{mmol} / 1(20.9 \pm 5.4 \mathrm{mg} / 100 \mathrm{ml})$, and $2.1 \pm 0.7$ $\mathrm{mmol} / \mathrm{l}(19 \cdot 1 \pm 6.4 \mathrm{mg} / 100 \mathrm{ml})$ respectively. Sixty-six cases of bacterial meningitis had CSF lactate levels ranging from $3.9 \mathrm{mmol} / 1(35.4 \mathrm{mg} / 100 \mathrm{ml})$ to greater than $10.0 \mathrm{mmol} / 1(90.0 \mathrm{mg} / 100 \mathrm{ml})$. Longitudinal studies in 7 children with bacterial meningitis showed that cerebrospinal fluid lactate levels differentiated bacterial from viral meningitis up to 4 days after starting treatment with antibiotics. Use of CSF lactate measurement for monitoring the efficacy of treatment is illustrated in a case of bacterial meningitis due to Pseudomonas aeruginosa. The origin of the cerebrospinal fluid lactate acidosis and the role of lactate in the pathophysiological cycle leading to intensification of brain tissue hypoxia and cellular damage is discussed with respect to the short-term prognosis and the long-term neurological sequelae.

With the advent of antibiotics three decades ago the mortality rate in bacterial meningitis was reduced from $50-90 \%$ to about $5-10 \%$. There has been no further comparable improvement since then. ${ }^{1-3}$ However studies on children with meningitis due to Haemophilus influenzae indicate that as many as $30 \%$ of the survivors suffer from severe neurological and psychological sequelae. ${ }^{3-5}$

To date there is no laboratory test which is both rapid and reliable for differentiating bacterial meningitis from viral meningitis or for quantitating the effectiveness of treatment. Results from a careful inspection of the cerebrospinal fluid (CSF) with complete differential cell count, and glucose and protein levels may still leave the differential diagnosis in doubt. ${ }^{6}$ Gram stains may be negative in as many as $30 \%$ of cases of culture-proved bacterial meningitis. ${ }^{7}$ Furthermore, treatment with antibiotics before initial lumbar puncture, which occurs in about half the cases of bacterial meningitis, ${ }^{8-12}$ increases both negative Gram stains and negative cultures. ${ }^{10}$

Several methods have been suggested for the rapid differential diagnosis of meningitis-such as CSF lactate dehydrogenase activity, ${ }^{13}$ counterimmunoelectrophoresis, ${ }^{14}$ nitroblue tetrazolium test, ${ }^{15}$ the limulus lysate test, ${ }^{16}$ and CSF $\mathrm{pH}$ measurement. However some of these tests produced more than $10 \%$ false-negative results, others detected only some types of organisms, and the equipment needed and the expertise required were beyond the scope of most clinical laboratories. Moreover there was decreased reliability if antibiotics had been given.

In 1917 Levinson $^{17}$ observed low $\mathrm{pH}$ values in the CSF of patients with bacterial meningitis, and believed this was due to lactic acid. In 1925 Killian $^{18}$ presented supporting data on CSF lactate from 5 normal patients and 25 patients with bacterial meningitis. In 1933 De Sanctis et al. ${ }^{19}$ concluded that variations in lactic acid of spinal fluid offered morereliable information about the clinical progress during treatment of bacterial meningitis than CSF sugar or total leucocyte counts.

Since Killian's report ${ }^{18}$ numerous papers have produced results in support of the measurement of CSF lactate levels in the differential diagnosis of meningitis. ${ }^{20-32}$ Despite this, the use of CSF lactate 
measurements as a rapid screening test for bacterial meningitis has not gained wide acceptance, primarily owing to the technical difficulties of its measurement.

This paper presents the results of our experience with CSF lactate measurement in normal children and children with meningitis using a rapid enzymatic micromethod suitable for a small clinical laboratory with standard laboratory equipment.

\section{Materials and methods}

CSF samples were obtained from 207 children aged between 2 days and 15 years. Each had had a lumbar puncture because of clinical features that suggested bacterial meningitis.

Complete differential cell count, a Gram stain, glucose and protein determinations were performed on each CSF sample.

No special preparation of the CSF was required for lactate determination except immediate centrifugation, using the supernatant if grossly bloodstained. If a sample could not immediately be assayed it was stored at a temperature of $-20^{\circ} \mathrm{C}$.

For this method ${ }^{33}$ lactate was converted to pyruvate by the enzyme lactic dehydrogenase (LDH EC 1.1.1.27) in a stoichiometric reaction with nicotinamide adenine dinucleotide (NAD+). Pyruvate inhibition of LDH was removed by reaction of the pyruvate with either glutamate pyruvate transaminase (GPT EC 2.6.1.2) to form alanine at $\mathrm{pH} 8 \cdot 9$, or alternatively, with hydrazine to form the hydrazone at $\mathrm{pH} 9 \cdot 5$. The increase in reduced nicotine adenine dinucleotide was measured fluorometrically or spectrophotometrically.

The assay protocol consisted of adding $2-10 \mu l$ of the CSF sample to $1.0 \mathrm{ml}$ of reaction mixture containing $25 \mathrm{ml}$ glutamate buffer (Sigma) to a concentration of $0 \cdot 120 \mathrm{~mol} / 1,60 \mathrm{ml}$ fresh glass distilled $\mathrm{H}_{2} \mathrm{O}, 5 \mathrm{ml}$ of NAD (Sigma grade III) to a concentration of $0.80 \mathrm{mmol} / \mathrm{l}$, and either 2 units $/ \mathrm{ml}$ of GPT (Boehringer Mannheim from pig heart) or $5 \mathrm{ml}$ of hydrazine (BDH AR grade) to a concentration of $0.103 \mathrm{~mol} / 1$, made up to $100 \mathrm{ml}$ with distilled $\mathrm{H}_{2} \mathrm{O}$.
Samples were measured in duplicate in $10 \times 75 \mathrm{~mm}$ Pyrex disposable tubes (Corning). Stock standard of lithium l-lactate $(10 \mathrm{mmol} / \mathrm{l})$ was diluted with the reaction mixture to $1 \mathrm{mmol} / \mathrm{l}$, and $0-50 \mu \mathrm{l}$ per tube containing 0-50 nmol/1 was used to construct a standard curve.

Fourteen units of LDH from rabbit muscle (Boehringer Mannheim) stored in tris buffer $20 \mathrm{mmol} / \mathrm{l}$, pH $8 \cdot 0$, and $0.02 \%$ bovine serum albumin were added to each tube.

The tubes were vortexed and incubated for 30 minutes at $37^{\circ} \mathrm{C}$, allowed to cool, and then read in either a Perkin Elmer fluorimeter 650 10S (on sensitivity 3 and slits $3 \mathrm{~nm}$, excitation wavelength $360 \mathrm{~nm}$, analytical wavelength $465 \mathrm{~nm}$ ) or a unicam SP 500 spectrophotometer at $365 \mathrm{~nm}$.

Each patient was placed in one of four groups. Group $1(\mathrm{n}=50)$. Normal, WBC $<0.005 \times 10^{9} / 1$ with no segmented neutrophils, normal glucose and protein, and a clear Gram stain. No cultures were set up on these samples.

Group $2(n=31)$. Viral meningitis, identified virus isolated from CSF.

Group $3(n=66)$. Bacterial meningitis, positive culture with identification of the organism.

Group $4(n=58)$. Miscellaneous, leucocytosis of unknown aetiology. These were presumed to be patients with viral meningitis from whose CSF no bacteria or virus could be isolated.

\section{Results}

CSF results for the four groups are given in Table 1.

The normal children all had CSF lactate levels less than $2.0 \mathrm{mmol} / 1(18.0 \mathrm{mg} / 100 \mathrm{ml}$ ) (mean and standard deviation $1 \cdot 3 \pm 0.3 \mathrm{mmol} / \mathrm{l}(11 \cdot 8 \pm 2 \cdot 7$ $\mathrm{mg} / 100 \mathrm{ml})$ ). Children with proved or suspected viral meningitis had CSF lactate levels less than $3.8 \mathrm{mmol} / \mathrm{l}(34.5 \mathrm{mg} / 100 \mathrm{ml})-2.3 \pm 0.6$ and $2 \cdot 1 \pm 0.7 \mathrm{mmol} / \mathrm{l}(20.9 \pm 5 \cdot 4$ and $19 \cdot 1 \pm 6 \cdot 4$ $\mathrm{mg} / 100 \mathrm{ml}$ ) respectively. Children with bacterial meningitis had CSF lactate levels from $3.9 \mathrm{mmol} / \mathrm{l}$ $(35.4 \mathrm{mg} / 100 \mathrm{ml})$ to greater than $10.0 \mathrm{mmol} / \mathrm{l}$

Table 1 CSF measurements (means and SD) made in 205 children

\begin{tabular}{|c|c|c|c|c|c|c|}
\hline Group & Median age (years) & $W B C\left(\times 10^{6} / l\right)$ & $\begin{array}{l}\% \text { segmented } \\
\text { neutrophils }\end{array}$ & Glucose (mmol/l) & Protein $(g / l)$ & Lactate ( $\mathrm{mmol} / \mathrm{l})$ \\
\hline $\begin{array}{l}\text { Normal }(n=50) \\
\text { Viral }(n=31)\end{array}$ & $\begin{array}{l}3 \cdot 8 \\
5 \cdot 0\end{array}$ & $\begin{array}{l}<5 \\
335 \\
(23-1250)\end{array}$ & $\begin{array}{l}0 \\
37 \\
(0-100)\end{array}$ & $\begin{array}{l}3 \cdot 4 \pm 0 \cdot 8 \\
3 \cdot 3 \pm 0.8\end{array}$ & $\begin{array}{l}<0 \cdot 30 \\
0 \cdot 10-5 \cdot 50\end{array}$ & $\begin{array}{l}1 \cdot 3 \pm 0.3 \\
2 \cdot 3 \pm 0 \cdot 6\end{array}$ \\
\hline Bacterial $(n=66)$ & $1 \cdot 1$ & $\begin{array}{l}8227 \\
(125-50000)\end{array}$ & $\begin{array}{l}81 \\
(2-100)\end{array}$ & $<1.0-3 \cdot 8$ & $0.15->10 \cdot 0$ & $3.9->10.0$ \\
\hline Others $(n=58)$ & $3 \cdot 7$ & $\begin{array}{l}572 \\
(100-3600)\end{array}$ & $\begin{array}{l}31 \\
(0-100)\end{array}$ & $3 \cdot 2 \pm 0.7$ & $0 \cdot 10->10.0$ & $2 \cdot 1 \pm 0 \cdot 7$ \\
\hline
\end{tabular}

Conversion: SI to traditional units: Lactate $1 \mathrm{mmol} / 1 \approx 9.0 \mathrm{mg} / 100 \mathrm{ml}$, glucose: $1 \mathrm{mmol} / 1 \approx 18 \mathrm{mg} / 100 \mathrm{ml}$.

Figures in brackets are ranges. 


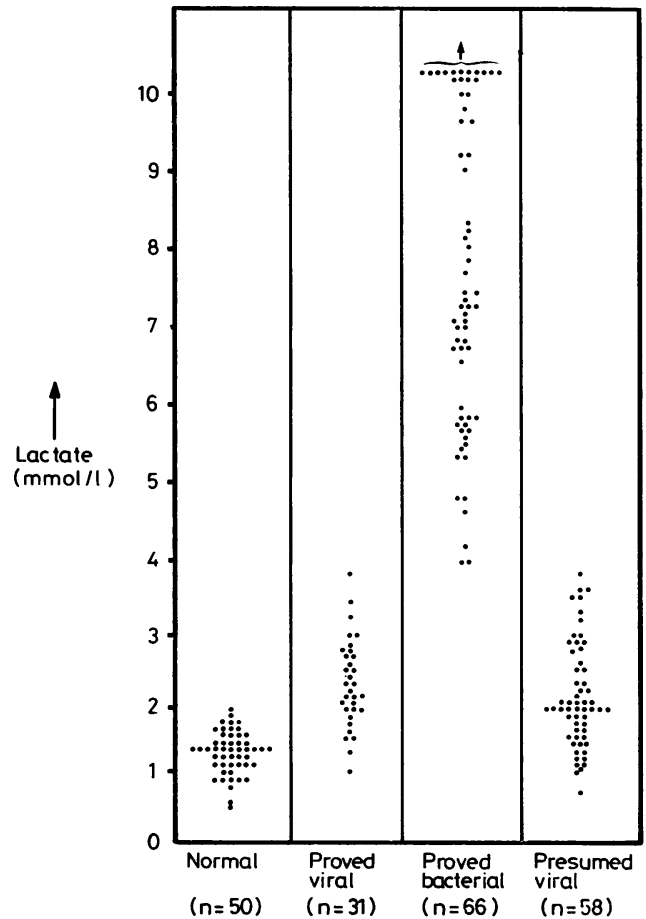

Fig. 1 CSF lactate levels in 205 children. Each dot represents level found in one child.

$(90.0 \mathrm{mg} / 100 \mathrm{ml})$. Individual levels from the 205 children are shown in Fig. 1.

Two false-negative results were obtained. One was from a child who had meningococcal septicaemia when an initial lumbar puncture showed WBC $0.002 \times 10^{9} / 1,1$ being a polymorph, RBC $0.014 \times$ $10^{9} / \mathrm{l}$, and a protein concentration of less than $0 \cdot 10 \mathrm{~g} / \mathrm{l}$; glucose was $4.1 \mathrm{mmol} / \mathrm{l}(73.8 \mathrm{mg} / 100 \mathrm{ml})$, lactate $2 \cdot 4 \mathrm{mmol} / \mathrm{l}(21 \cdot 8 \mathrm{mg} / 100 \mathrm{ml})$, and the Gram stain was clear. However a culture grew Neisseria meningitidis. Because the child's condition rapidly deteriorated a second lumbar puncture was performed 8 hours later; this showed WBC $8.85 \times 10^{9} / 1$, $98 \%$ polymorphs, protein $2.5 \mathrm{~g} / \mathrm{l}$, glucose $1.5 \mathrm{mmol} / 1$ $(27 \mathrm{mg} / 100 \mathrm{ml})$, and lactate $10 \cdot 0 \mathrm{mmol} / 1(90 \mathrm{mg} /$ $100 \mathrm{ml}$ ).

The other false-negative result was also from a child with septicaemia, the lactate changing from $2 \cdot 2 \mathrm{mmol} / \mathrm{l}(20 \mathrm{mg} / 100 \mathrm{ml})$ to $15 \cdot 4 \mathrm{mmol} / \mathrm{l}(140 \mathrm{mg} /$ $100 \mathrm{ml}$ ) in 12 hours.

Thirty-nine per cent of patients in the bacterial group had had treatment with antibiotics.

A breakdown of the various agents responsible for meningitis in the viral and bacterial groups is given in Table 2 .
Table 2 Causative agents in groups 2 and 3

\begin{tabular}{lr}
\hline Group 2 & No \\
Viral meningitis & \\
Mumps virus & 15 \\
Echo 30 & 6 \\
Coxsackie B4 & 4 \\
Coxsackie B3 & 3 \\
Echo 11 & 2 \\
Coxsackie B2 & 1 \\
Group 3 & \\
Bacterial meningitis & \\
Haemophilus influenzae & 30 \\
Streptococcus pneumoniae & 14 \\
Neisseria meningitidis & 13 \\
Escherichia coli & 4 \\
Group B streptococci & 2 \\
Pseudomonas aeruginosa & 1 \\
Klebsiella aerogenes & 1 \\
Citrobacter diversus & 1 \\
\hline
\end{tabular}

Fig. 2 shows the effect of antibiotics on lactate levels in 7 children with bacterial meningitis. Three had infections due to Escherichia sp., one with $H$. influenzae, one with Pseudomonas aeruginosa, one with Citrobacter diversus, and one with $N$. meningitis group $\mathrm{A}$. In each case the organism was sensitive to the antibiotic that was given parenterally in appropriate doses.

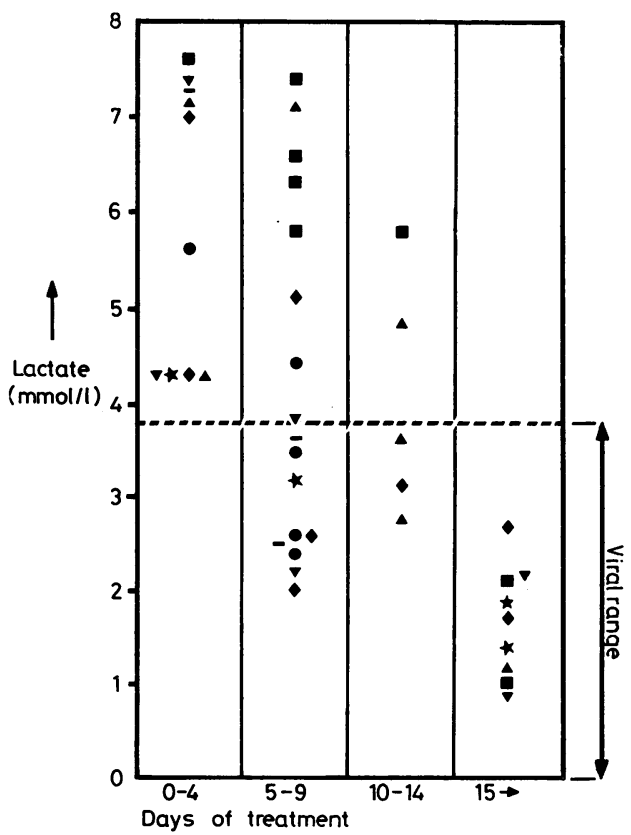

Fig. 2 Effect of treatment with antibiotics on CSF lactate in 7 children with bacterial meningitis. Levels measured in any one child on different days are shown by same symbol. 


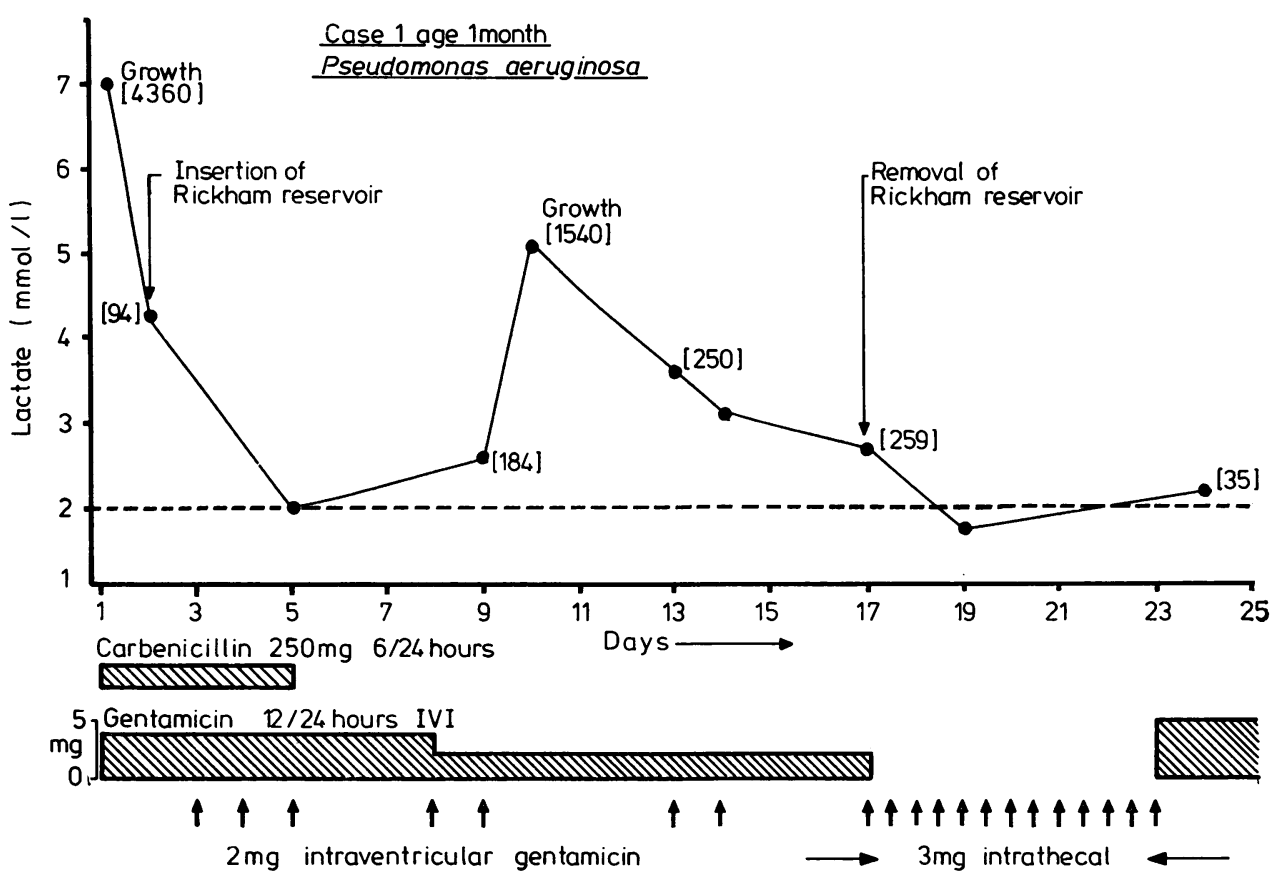

Fig. 3 CSF lactate profile in a patient with meningitis due to Pseudomonas aeruginosa. Figures in brackets are $W B C \times 10^{6}$. Dotted line represents upper limit to the normal range.

An individual response of lactate to antibiotic treatment of bacterial meningitis is illustrated in Fig. 3. This patient, a 1-month-old boy (Case 1), was admitted with a history of persistent central nervous system infection due to $P$. aeruginosa that did not respond well to 21 days of parenteral gentamicin treatment. An initial CSF sample on admission showed WBC $4.3 \times 10^{9} / 1$ of which $85 \%$ were polymorphs, protein greater than $10 \mathrm{~g} / \mathrm{l}$, glucose $2.0 \mathrm{mmol} / 1(18.0 \mathrm{mg} / 100 \mathrm{ml})$, and lactate $7.0 \mathrm{mmol} / 1$ $(63.6 \mathrm{mg} / 100 \mathrm{ml})$. A culture of the CSF subsequently grew $P$. aeruginosa. Treatment with intravenous gentamicin ( $4 \mathrm{mg}$ twice daily) and carbenicillin ( $250 \mathrm{mg}$ four times daily) was started on day 1, followed by intraventricular gentamicin ( $2 \mathrm{mg}$ daily) on day 3 after insertion of a Rickham reservoir.

His clinical condition improved with a rapid fall in leucocytes in his CSF, and the lactate level was $2.0 \mathrm{mmol} / \mathrm{l}(18.0 \mathrm{mg} / 100 \mathrm{ml})$ on day 5 when carbenicillin was stopped because the organism was shown to be resistant to it. Intraventricular gentamicin was also stopped and on day 8 the dose of intravenous gentamicin dose was halved. Later that day he became febrile, a CSF sample on day 10 showed WBC $1.54 \times 10^{9} / 1$ of which $75 \%$ were polymorphs, protein greater than $10 \mathrm{~g} / \mathrm{l}$, glucose
$1.9 \mathrm{mmol} / \mathrm{l}(34.2 \mathrm{mg} / 100 \mathrm{ml})$, and a lactate level of $5 \cdot 1 \mathrm{mmol} / 1(46 \cdot 3 \mathrm{mg} / 100 \mathrm{ml})$. A culture of this sample again showed growth of $P$. aeruginosa.

Treatment with gentamicin was continued systemically, intraventricularly, and, finally, intrathecally (after removal of the Rickham reservoir on day 17). There was a progressive clinical improvement with a concomitant fall in the level of CSF lactate.

\section{Discussion}

The fact that CSF lactate levels overlap between the normal and viral groups has been observed by others (Table 3). In the present series CSF lactate levels were higher than in viral meningitis in all cases of bacterial meningitis with the exception of two. These 2 false-negatives show that the CSF lactate level is a measure of hypoxic brain damage rather than an indicator of organisms. Theoretically there must be some point at which an organism responsible for the septicaemia crosses the blood brain barrier. While it is present in the CSF of the child with meningitis there would be a time lag before any appreciable central nervous system damage takes place and the lactate level becomes increased. These results show 
Table 3 CSF lactate levels taken from other reports

\begin{tabular}{|c|c|c|c|c|c|}
\hline \multicolumn{2}{|c|}{ Reference } & \multirow{2}{*}{$\begin{array}{l}\text { Controls } \\
(\mathrm{mmol} / \mathrm{l})\end{array}$} & \multicolumn{2}{|l|}{ Meningitis } & \multirow[t]{2}{*}{ Method } \\
\hline No & Date & & $\begin{array}{l}\text { Viral } \\
(\mathrm{mmol} / \mathrm{l})\end{array}$ & $\begin{array}{l}\text { Bacterial } \\
(\text { mmol } / l)\end{array}$ & \\
\hline 18 & 1925 & $\begin{array}{l}0 \cdot 9-1 \cdot 7 \\
(n=5)\end{array}$ & - & $\begin{array}{l}1 \cdot 2-8 \cdot 5 \\
(\mathrm{n}=17)\end{array}$ & Colorimetric \\
\hline 19 & 1933 & $1 \cdot 3-1 \cdot 8$ & - & $\begin{array}{l}3 \cdot 0-19 \cdot 6 \\
(n=27)\end{array}$ & Colorimetric \\
\hline 20 & 1964 & $\begin{array}{l}1 \cdot 6 \pm 0 \cdot 4 \\
(n=23)\end{array}$ & $\begin{array}{l}2 \cdot 0 \pm 0 \cdot 2 \\
(n=5)\end{array}$ & $\begin{array}{l}6 \cdot 6-21 \cdot 5 \\
(n=10)\end{array}$ & Enzymatic \\
\hline 21 & 1970 & $\begin{array}{l}1 \cdot 6 \pm 02 . \\
(n=20)\end{array}$ & $\begin{array}{l}2 \cdot 3 \pm 0 \cdot 8 \\
(n=17)\end{array}$ & $\begin{array}{l}6 \cdot 7 \pm 41 \cdot 8 \\
(n=19)\end{array}$ & Colorimetric \\
\hline 22 & 1972 & $\begin{array}{l}1 \cdot 7 \pm 0 \cdot 6 \\
(n=46)\end{array}$ & $\begin{array}{l}2 \cdot 1 \pm 0 \cdot 7 \\
(n=35)\end{array}$ & $\begin{array}{l}7 \cdot 2 \pm 2 \cdot 1 \\
(n=21)\end{array}$ & Enzymatic \\
\hline 23 & 1974 & $\begin{array}{l}1 \cdot 6 \pm 0 \cdot 1 \\
(n=25)\end{array}$ & $\begin{array}{l}2 \cdot 2 \pm 1 \\
(\mathrm{n}=25)\end{array}$ & $\begin{array}{l}8 \cdot 3 \pm 0 \cdot 7 \\
(n=15)\end{array}$ & Enzymatic \\
\hline 24 & 1977 & $\begin{array}{l}1 \cdot 5 \pm 0 \cdot 7 \\
(n=20)\end{array}$ & $\begin{array}{l}1 \cdot 5 \pm 0 \cdot 7 \\
(n=36)\end{array}$ & $\begin{array}{l}6 \cdot 0 \pm 1 \cdot 9 \\
(n=16)\end{array}$ & Enzymatic \\
\hline 26 & 1977 & $\begin{array}{l}0.5-8 \cdot 4 \\
(n=106)\end{array}$ & $\begin{array}{l}1 \cdot 1-5 \cdot 0 \\
(n=15)\end{array}$ & $\begin{array}{l}8 \cdot 0+28 \cdot 5 \\
(n=8)\end{array}$ & GLC \\
\hline 28 & 1977 & $\begin{array}{l}1 \cdot 3 \pm 0 \cdot 6 \\
(n=10)\end{array}$ & $\begin{array}{l}2 \cdot 1 \pm 0 \cdot 7 \\
(n=10)\end{array}$ & $\begin{array}{l}6 \cdot 4 \pm 3 \cdot 6 \\
(n=22)\end{array}$ & Colorimetric \\
\hline 30 & 1978 & $\begin{array}{l}1 \cdot 6 \pm 0 \cdot 8 \\
(n=25)\end{array}$ & $\begin{array}{l}2 \cdot 3 \pm 1 \cdot 0 \\
(n=26)\end{array}$ & $\begin{array}{l}6 \cdot 5 \pm 1 \cdot 0 \\
(n=4)\end{array}$ & GLC \\
\hline \multicolumn{2}{|c|}{ This report } & $\begin{array}{l}1 \cdot 3 \pm 0 \cdot 3 \\
(n=50)\end{array}$ & $\begin{array}{l}2 \cdot 3 \pm 0 \cdot 6 \\
(n=31)\end{array}$ & $\begin{array}{l}3 \cdot 9->10 \cdot 0 \\
(n=66)\end{array}$ & Enzymatic \\
\hline
\end{tabular}

that this time lag is less than 8 hours and may in fact only be a matter of minutes.

Thus CSF lactate levels could be used to differentiate bacterial from viral meningitis in most of our cases. Some studies have described such an overlap especially in cases of tuberculous meningitis. ${ }^{24} 2832$ We had only one child who was clinically diagnosed as having tuberculous meningitis but in whom no organism could be cultured; the CSF lactate was $3.5 \mathrm{mmol} / \mathrm{l}(31.8 \mathrm{mg} / 100 \mathrm{ml})$. Brook et al..$^{30}$ have shown that there is no age or sex difference in CSF lactate levels regardless of the aetiological group.

All CSF measurements (Table 1) were similar for the viral and miscellaneous groups, as would be expected.

The CSF lactate levels in the 7 treated patients with bacterial meningitis (Fig. 2) showed that such children could still be distinguished from children with viral meningitis up to 4 days after starting antibiotics.

The decrease in lactate levels after initiation of antibiotic treatment in the 7 patients agrees with other studies. ${ }^{181921222428}$ The time for the lactate concentration to reach viral levels in these reports varied from 1 to 5 days. It is evident from our results as well as those from other reports that each child responds in a different manner. Brook et al. ${ }^{30}$ showed that the rate of decrease was dependent on the type of organism, tuberculous meningitis requiring more than 6 weeks before lactate levels reached normal levels. Since lactate is cleared only slowly from the CSF by diffusion into the brain tissue, ${ }^{34} \mathbf{3 5}^{35}$ the lactate level before starting treatment and the 'aggressiveness' of treatment would be two additional factors.

The lactate profile in Case 1 (Fig. 3) illustrates the potential use of CSF lactate for monitoring the effectiveness of treatment in bacterial meningitis. The initial rapid fall in CSF lactate levels from $7.0 \mathrm{mmol} / 1$ $(63.6 \mathrm{mg} / 100 \mathrm{ml})$ on day 1 to $2.0 \mathrm{mmol} / \mathrm{l}(18.0 \mathrm{mg} /$ $100 \mathrm{ml}$ ) on day 5 took place when the leucocyte count was falling, cultures were negative, and there were signs of clinical improvement. Synergism between carbenicillin and gentamicin ${ }^{36}$ together with combined intravenous and intraventricular gentamicin might have been responsible for this rapid improvement. The fact that carbenicillin was stopped on this day, and the intravenous dose of gentamicin halved on day 8 (at a time when the penetration of gentamicin through the blood brain barrier might have been decreasing ${ }^{37}$ ) and the fact that intraventricular gentamicin was given only sporadically would explain the reisolation of the organism on day 10. The lactate rose to $5 \cdot 1 \mathrm{mmol} / \mathrm{l}(46 \cdot 3 \mathrm{mg} / 100 \mathrm{ml})$ during this period demonstrating that the biochemical deterioration was parallel to the clinical condition. Intravenous, intraventricular, and intrathecal treatment with gentamicin was continued and this produced asepsis associated with virtually normal lactate levels.

Despite many suggestions, the cause of the lactic acidosis in bacterial meningitis is still not clear. ${ }^{38}$ Montani and Perret ${ }^{20}$ claimed that the CSF lactate level was dependent on two factors-the number of organisms and the number of leucocytes present. The relationship to the number of leucocytes is debatable for a number of reasons. Firstly only a small amount of lactate is produced by endotoxin-stimulated leucocytes, ${ }^{38-40}$ increased CSF lactate occurs in tuberculous meningitis in patients with few bacteria and a mononuclear cellular response, ${ }^{41}$ and CSF lactic acidosis can be found in severe cases of acute encephalitis in the presence of a low leucocyte count. Hansen et al $^{42}$ suggested the increase in lactate was due partly to inflamed brain tissue and partly to decerebrate rigidity and convulsions. Simpson et al ${ }^{43}$ demonstrated moderate increases in CSF lactate in 7 of 22 patients with prolonged seizures (longer than 30 minutes) or recurrent short convulsions.

Kopetzky and Fishberg ${ }^{44}$ suggested that the lactic acidosis in purulent meningitis might be due to a decrease in cerebral blood supply caused by increased intracranial pressure. In fact a moderate increase in intracranial pressure will appreciably reduce cerebral perfusion pressure thereby reducing cerebral blood flow, shifting brain metabolism from aerobic to anaerobic glycolysis, with increased lactate levels in 
brain tissue and CSF. ${ }^{45} 46$ Raisis et al. $^{47}$ have demonstrated the dependence of cellular oxidative metabolism on the maintenance of adequate perfusion pressure in hydrocephalus, and Paulson et al $^{48}$ found that cerebral blood flow was decreased by as much as $40 \%$ in pyogenic meningitis, while CSF lactate was increased, CSF bicarbonate reduced, and autoregulation often impaired.

CSF hydrogen ion concentration and lactate are concerned in a cycle of pathophysiological mechanisms (Fig. 4) involving vasoparalysis with the loss of vasomotor autoregulation, $\mathrm{CO}_{2}$ regulation of vasomotor tone, resulting in the spreading of initially localised oedema. ${ }^{49}$ Thus CSF lactic acidosis is dangerous because of its intensification of tissue hypoxia.

It is worth noting that several studies ${ }^{50-54}$ on conditions other than infection indicate that CSF lactate levels below $3.0 \mathrm{mmol} / 1(27 \mathrm{mg} / 100 \mathrm{ml})$ are neurologically 'safe' while values above $4.0 \mathrm{mmol} / 1$ $(36 \mathrm{mg} / 100 \mathrm{ml})$ are found in life-threatening states in which survival could lead to permanent neurological damage. This suggests the prognostic value of CSF lactate in determining cellular damage, and may prove to correlate with the long-term neurological and psychological deficits observed in children surviving bacterial meningitis.

Seitz and Ocker, ${ }^{54}$ in an attempt to break the vicious circle (Fig. 4) that leads to non-reversible hypoxia in the brain tissue of severely brain-injured patients with CSF lactic acidosis, used a solution of $8 \cdot 4 \%$ sodium bicarbonate administered intrathecally. This treatment resulted in an increase in overall cerebral blood flow of $33 \%$, with $60 \%$ of the patients showing an improvement in clinical condition.

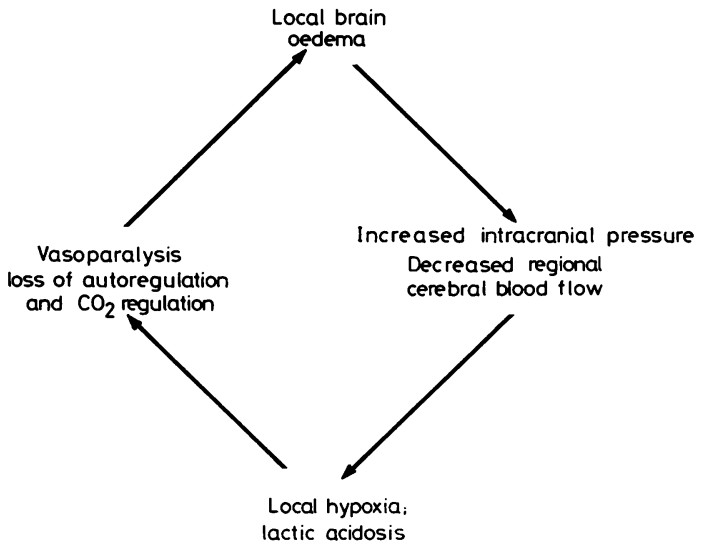

Fig. 4 Pathophysiology of CSF lactic acidosis.
The rehabilitation of such patients improved and the mortality rate was reduced.

This study confirms the value of the estimation of CSF lactate as a diagnostic aid in meningitis. It also indicates the potential of lactate as a biochemical measurement for monitoring the efficacy of treatment in bacterial meningitis. With respect to short-term prognosis and the long-term neurological sequelae, the possible use of intrathecal sodium bicarbonate in the treatment of severe brain injury with lifethreatening CSF lactic acidosis would seem worthy of investigation in bacterial meningitis.

We thank Dr $\mathrm{H}$ Kilham and Dr $\mathrm{H}$ Kitson for constructive criticism and Lina Pipitone for secretarial expertise.

\section{References}

1 Public Health Service: Epidemiological Research Laboratory. Deaths from bacterial meningitis. $\mathrm{Br} \mathrm{Med} \mathrm{J}$ 1975; iii: 714-5.

2 Nyhan W L, Richardson F. Complications of meningitis. Annu Rev Med 1963; 14: 243-60.

3 Sproles E T, III, Azerrad J, Williamson C, Merrill R E. Meningitis due to Hemophilus influenzae: long term sequelae. J Pediatr 1969; 75: 82-8.

4 Lindberg J, Rosenhall U, Nylén O, Ringér A. Long term outcome of Hemophilus influenzae meningitis related to antibiotic treatment. Pediatrics $1977 ; 60: 1-13$.

5 Sell S H W, Merrill R E, Doyne E O, Zimsky E P, Jr. Long term sequelae of Hemophilus influenzae meningitis. Pediatrics 1972; 49: 206-11.

6 Feigin R D, Shackelford P G. Value of repeat lumbar puncture in differential diagnosis of meningitis. $N$ Engl $J$ Med 1973; 289: 571-4.

7 Hyslop N E, Swartz M N. Bacterial meningitis. Postgrad Med 1975; 58: 120-8.

8 Harter D H. Preliminary antibiotic therapy in bacterial meningitis. Arch Neurol 1963; 9: 343-7.

9 Dalton H P, Allison M J. Modification of laboratory results by partial treatment of bacterial meningitis. $\mathrm{Am} \mathrm{J}$ Clin Pathol 1968; 49: 410-3.

10 Jarvis C W, Saxena K M. Does prior antibiotic treatment hamper the diagnosis of acute bacterial meningitis? Clin Pediatr (Phila) 1972; 11 : 201-4.

11 Converse G M, Gwaltney J M, Jr, Strassburg D A, Hendley $\mathbf{J} \mathbf{O}$. Alteration of cerebrospinal fluid findings by partial treatment of bacterial meningitis. J Pediatr 1973; 83: $220-5$.

12 Quaade F, Kristensen K P. Purulent meningitis: a review of 658 cases. Acta Med Scand 1962; 171: 543-50.

13 Neches W, Platt M. Cerebrospinal fluid LDH in 287 children, including 53 cases of meningitis of bacterial and non-bacterial etiology. Pediatrics 1968; 41: 1097-103.

14 Coonrod J D, Rytel M W. Determination of aetiology of bacterial meningitis by counterimmunoelectrophoresis. Lancet 1972 ; i: 1154-7.

15 Fikrig S M, Berkovich S, Emmett S M, Gordon C. Nitroblue tetrazolium dye test and differential diagnosis of meningitis. $J$ Pediatr 1973; 82: 855-62.

16 Nachum R, Lipsey A, Siegel S E. Rapid detection of Gram-negative bacterial meningitis by the limulus lysate test. $N$ Engl J Med 1973; 289: 931-7. 
17 Levinson A. The hydrogen ion concentration of cerebrospinal fluid: studies in meningitis. J Infect Dis 1917; 21: 556-70.

18 Killian J A. Lactic acid of normal and pathological spinal fluids. Proc Exp Biol Med 1925; 23: 255-7.

19 De Sanctis A G, Killian J A, Garcia T. Lactic acid of spinal fluid in meningitis. Am J Dis Child 1933; 46: 239-49.

20 Montani S, Perret C. Acidose lactique du liquide céphalorachidien dans les méningites bactériennes. Schweiz Med Wochenschr 1964; 44: 1552-7.

21 Yalaz K. Cerebrospinal fluid lactate concentration in neurologically normal and abnormal children. Turk $J$ Pediatr 1970; 12: 8-15.

22 Lamisse F, Grenier B, Choutet P, Rolland J C, Gautier J. Interet du dosage du l'acide lactique dans le liquide rachidien pour le diagnostic des meningites purulentes. Lyon Méd 1972; 228: 591-5.

23 Bland R D, Lister R C, Ries J P. Cerebrospinal fluid, lactic acid level, and $\mathrm{pH}$ in meningitis. Am J Dis Child 1974; 128: $151-6$.

24 Fiero H, Chacon A, Gutierrez G, Munoz O. Valores de pH y ácido láctico en el liquidae cefalerraquideo como ayuada diagnóstica para differenciar meningeoencefalitis viral y purulenta. Arch Invest Med (Mex) 1977; 8: 185-92.

25 Controni G, Rodriguez W J, Hicks J M, et al. Cerebrospinal fluid lactic acid levels in meningitis. J Pediatr 1977; 91 : $379-84$.

26 Ferguson I R, Tearle P V. Gas liquid chromatography in the rapid diagnosis of meningitis. J Clin Pathol 1977; 30: $1163-7$.

27 Lauwers S. Apport du dosage d'acide lactique dans le LCR au diagnostic differéntiel des méningites. Acta Clin Belg 1977; 32: 319-25.

28 Gandhi P C, Khan M A, Mathur P S, Singh V. Lactic acid levels in cerebrospinal fluid in various meningitides in infancy and childhood. Indian Pediatr 1977; 14: 505-10.

29 Hurd C A, Fennema K J, Blazevic D J. Use of cerebrospinal fluid lactate levels in the diagnosis of bacterial meningitis. Am J Med Technol 1978; 44: 11-3.

30 Brook I, Bricknell K S, Overturf G D, Finegold S M. Measurement of lactic acid in cerebrospinal fluid of patients with infections of the central nervous system. J Infect Dis 1978; 137: 384-90.

31 Komorowski R A, Farmer S G, Hanson G A, Hause L L. Cerebrospinal fluid lactate acid in diagnosis of meningitis. $J$ Clin Microbiol 1978; 8: 89-92.

32 D'Souza E, Mandal B K, Hooper J, Parker L. Letter: Lactic acid concentration in cerebrospinal fluid and differential diagnosis of meningitis. Lancet 1978; ii: 579-80.

33 Noll F. Determination of L-lactate with LDH, GPT, and NAD. In: Bergmeyer $\mathrm{H}$ U, ed. Methods of enzymatic analysis. Vol. 3. London: Verlag Chemie Weinheim/ Academic Press, 1974: 1475-9.

34 Prockop L D. Cerebrospinal fluid lactic acid clearance and effect on facilitated diffusion of a glucose analogue. Neurology (Minneap) 1968; 18: 189-96.

35 Valenca L M, Shannon D C, Kazemi H. Clearance of lactate from the cerebrospinal fluid. Neurology (Minneap) 1971; 21 : 615-20.

36 Holmes R K, Minshew B H, Sanford P J. Resistance of Pseudomonas aeruginosa to aminoglycoside antibiotics. J Infect Dis 1974; 130: S163-6.

37 Smith D H, Ingram D L, Smith A L, Gilles F, Bresnan M J. Bacterial meningitis: a symposium. Pediatrics 1973; 52: $586-600$.
${ }_{38}$ Menkes $\mathrm{J} \mathbf{H}$. The causes for low spinal fluid sugar in bacterial meningitis: another look. Pediatrics 1969; 44: 1-3.

39 Cohn Z A, Morse S I. Functional and metabolic properties of polymorphonuclear leucocytes. II. The influence of a lipopolysaccharide endotoxin. J Exp Med 1960; 111: 689-704.

40 Himwich W A, Himwich H E. Pyruvic acid exchange of the brain. J Neurophysiol 1964; 9: 133-6.

41 Sudre Y, Reiss D. Interêt du dosage de l'acide du liquide céphalo-rachidien dans les méningites. Bordeaux Med $1969 ; 2$ : 2045-57.

42 Hansen E L, Kristensen H S, Brodersen P, Paulson O B, Müllertz S, Jessen $O$. Acid base pattern of cerebrospinal fluid and arterial blood in bacterial meningitis and in encephalitis. Acta Med Scand 1974; 196: 431-7.

43 Simpson H, Habel A H, George E L. Cerebrospinal fluid acid-base status and lactate and pyruvate concentrations after convulsions of varied duration and aetiology in children. Arch Dis Child 1977; 52: 844-9.

44 Kopetzky S J, Fishberg E H. Changes in distribution ratio of constituents of blood and spinal fluid in meningitis. $J$ Lab Clin Med 1933; 18: 796-801.

${ }^{45}$ Langfitt $\mathrm{T}$ W. Increased intracranial pressure. Clin Neurosurg 1968; 16: 436-71.

46 Zwetnow N N. Effects of increased cerebrospinal fluid pressure on the blood flow and on the energy metabolism of the brain. An experimental study. Acta Physiol Scand [Suppl] 1970; Supplement 339, 1-28.

47 Raisis J E, Kindt G W, McGillicuddy J E, Miller C A. Cerebrospinal fluid lactate and lactate/pyruvate ratios in hydrocephalus. J Neurosurg $1976 ; 44$ : 337-41.

48 Paulson O B, Brodersen P, Hansen E L, Kristensen H S. Regional cerebral blood flow cerebral metabolic rate of oxygen and cerebrospinal fluid acid-base variables in patients with acute meningitis and with acute encephalitis. Acta Med Scand 1974; 196: 191-8.

49 Reulen H J, Hadjidimos A, Hase U. Steroids in the treatment of brain edema. Adv Neurosurg 1973; 1: 92-105.

50 Crockard H A, Taylor A R. Serial CSF lactate/pyruvate values as a guide to prognosis in head injury coma. Eur Neurol 1972; 8: 151-7.

51 Czernicki Z, Grochowski W. Cerebrospinal fluid lactates following craniocerebral injuries (in Polish). Neurol Neurochir Pol 1976; 10: 651-3.

52 Raudam E I, Rivis E K. The prognostic value of the lactate concentration and the lactate/pyruvate ratio in cerebrospinal fluid following acute cerebral circulatory disorders (in Russian). Vopr Neirokhir 1976; 2: 32-7.

53 Cold G, Enevoldsen E, Malmros R. Ventricular fluid lactate, pyruvate, bicarbonate, and $\mathrm{pH}$ in unconscious brain-injured patients subjected to controlled ventilation. Acta Neurol Scand 1975; 52: 187-95.

54 Seitz H D, Ocker K. The prognostic and therapeutic importance of changes in the CSF during the acute stage of brain injury. Acta Neurochir (Wien) 1977; 39: 211-31.

Correspondence to $\mathrm{Mr} \mathrm{J}$ Eross, Department of Endocrinology, Royal Alexandra Hospital for Children, Camperdown, Sydney, New South Wales 2050, Australia.

Received 9 June 1980 